\title{
PRODUCT PLACEMENT IN THE FILM ADA APA DENGAN CINTA
}

\author{
Amelia Putri Santika ${ }^{1}$ dan Ana Rosmiati ${ }^{2}$ \\ ${ }^{1}$ Institut Seni Indonesia (ISI) Surakarta, Indonesia \\ ${ }^{2}$ Institut Seni Indonesia (ISI) Surakarta, Indonesia \\ E-mail: ana.rosmiatii@yahoo.com
}

\begin{abstract}
Nowdays film is not only a medium of entertainment, but also a medium for product promotion or as a medium for advertising products or public service advertisements. This function can be found in the film Ada Apa Dengan Cinta 2. The purpose of this study is to analyze the characteristic of the product advertisement inserted in the film Ada Apa dengan Cinta 2. The type of research used is Descriptive Qualitative. Data collection techniques using Purposive Sampling to obtain three research samples, namely Aqua, Loreal, and Line. Data analysis was done by Interpretative Video-Analysis. The results showed that in the film Ada Apa dengan Cinta 2 there are four adverts characteristic, namely: Public Presentation appears in 1 scene, Persuasiveness appears in 2 scenes, Amplified Expresiveness appears in 2 scenes, and Impersonality appears in 4 scenes. The product placement in this film appears that the Impersonality advertisement is very dominant, then followed by the Amplified Expresiveness and Persuasiveness advertisement. Meanwhile, advertising in a Public Presentation characteristic only appears in one scene.
\end{abstract}

Keywords: Film, advertising, product placement, and Ada Apa Dengan Cinta 2

\begin{abstract}
ABSTRAK
Era sekarang ini film bukan hanya menjadi media hiburan saja, namun juga menjadi media promosi produk atau sebagai media untuk mengiklankan produk atau iklan layanan masyarakat. Fungsi ini dapat dijumpai pada film Ada Apa Dengan Cinta 2. Tujuan dalam penelitian ini adalah menganalisis sifat iklan produk yang disisipkan dalam film Ada Apa Dengan Cinta 2. Jenis penelitian yang digunakan adalah Deskriptif Kualitatif. Teknik pengambilan data dengan menggunakan Purposive Sampling sehingga diperoleh tiga sampel penelitian yaitu Aqua, Loreal, dan Line. Analisa data dilakukan dengan Interpretative VideoAnalysis. Hasil penelitian menunjukkan pada film Ada Apa Dengan Cinta 2 ini terdapat empat sifat iklan yaitu: Public Presentation tampak pada 1 adegan, Persuasiveness tampak pada 2 adegan, Amplified Expresiveness tampak pada 2 adegan, dan Impersonality tampak pada 4 adegan. Penempatan produk dalam film ini tampak bahwa iklan Impersonality sangat mendominasi, kemudian disusul oleh iklan Amplified Expresiveness dan Persuasiveness. Adapun, iklan bersifat Public Presentation hanya tampak pada satu adegan saja.
\end{abstract}

Kata kunci: Film, iklan, penempatan produk, dan Ada Apa Dengan Cinta 2

\section{PENDAHULUAN}

Dunia hiburan khususnya perfilman mengalami perkembangan yang sangat pesat dikarenakan kemajuan teknologi dan perubahan zaman, bukan hanya dari efek yang ditampilkan, dan aktor pemeran saja, namun alur cerita yang disajikan dan pesan yang disampaikan juga sudah sangat jelas. Kualitas film ditentukan baik oleh segi sinamatik maupun segi naratifnya sebagai 


\section{CAPTURE}

unsur pembentuk film (Ali \& Sugihartono, 2015).

Saat ini, film tidak serta merta menjadi tontonan dan hiburan semata, tetapi juga menjadi bisnis dan industri yang menjanjikan. Film terdapat beberapa genre yang ada di antaranya action, komedi, horror, drama, animasi, biografi, dan masih banyak lagi. Film merupakan salah satu media hiburan yang digemari oleh masyarakat. Melalui film, masyarakat tidak hanya mendapatkan hiburan dan tontonan semata, karena banyak film yang mengandung nilai edukasi atau pembelajaran.

Kemajuan teknologi mendorong makin berkembangnya bisnis instan cepat lewat penyisipan iklan ke dalam sebuah sajian di film layar lebar ataupun juga film televisi (FTV). Tidak serta merta produk yang disisipkan mampu sejalan dengan alur cerita, tetapi ada juga yang melenceng dari jalan cerita yang sudah ditentukan. Hal ini menjadikan penyisipan produk ke dalam film kadang tidak masuk akal atau terkesan melebih-lebihkan, sehingga bisa mempengaruhi pemirsa. Apabila hal ini terus berlanjut, maka masyarakatlah yang mampu menilai product placement tersebut dengan objektivitas yang berbeda antara masing-masing individu. Faktanya dalam industri perfilman terutama di Indonesia, banyak sekali film yang di dalamnya terdapat produk-produk yang disisipkan pada adegan film tersebut. Beberapa film yang menyisipkan beberapa produk di dalamnya adalah film Habibie Ainun, Di bawah Lindungan Ka'bah, $5 \mathrm{~cm}$, dan film Ada Apa Dengan Cinta 2.

Era sekarang ini film bukan hanya menjadi media hiburan saja, namun film juga menjadi media promosi sebuah produk atau sebagai media untuk mengiklankan suatu produk atau iklan layanan masyarakat. Maka dari itu, banyak pemasar yang menyisipkan produknya ke dalam sebuah film atau sering juga disebut penempatan produk (Produk Placement). Penempatan suatu produk dalam film bisa merupakan proses yang sederhana yaitu bagaimana suatu produk digunakan dalam salah satu adegan dalam bentuk merek disebutkan oleh seorang tokoh dalam cerita atau sebuah logo dapat terlihat di latar belakang frame (Shrum, 2010). Salah satu film populer adalah film Ada Apa Dengan Cinta 2 terdapat beberapa produk yang disisipkan antara lain Aqua, Loreal Paris, Lenovo, Garuda Indonesia, Walls Magnum, Line, Mitsubishi, dan Fuji Film. Pemilihan film Ada Apa Dengan Cinta 2 memiliki alasan tersendiri, karena film ini memang sudah lama sekali ditunggu-tunggu oleh penonton. Selain itu, cerita dalam film ini disajikan menarik dan mengundang penasaran penonton untuk melihatnya.

Penempatan produk dalam film yang ber-genre drama ini sangat menarik untuk dikaji karena film ini banyak mengandung produk-produk yang 
disisipkan oleh produsen atau pemasar. Maka, penelitian tentang penempatan produk dalam film Ada Apa Dengan Cinta 2 bertujuan untuk menemukan produk-produk yang sengaja disisipkan lewat media film. Penelitian ini lebih menekankan pada sesuai atau tidaknya penempatan produk dalam alur film. Penelitian ini menganalisa penempatan beberapa produk yang ditinjau dari sifat iklan. Penelitian ini hanya dilakukan terhadap beberapa produk saja yang dipilih untuk dianalisia. Beberapa brand produk tersebut adalah Line, Aqua, dan Loreal. Alasan mengapa memilih brand tersebut dikarenakan: pertama, brand tersebut beberapa kali tayang; kedua, beberapa brand tersebut merupakan sponsor utama film tersebut dan berkaitan dengan film Ada Apa Dengan Cinta 2.

Masalah dalam penelitian ini adalah bagaimana penempatan produk dalam film Ada Apa Dengan Cinta 2 jika ditinjau dari sifat iklannya? Tujuan yang ingin dicapai dalam penelitian ini adalah mendeskripsikan penempatan produk Aqua, Loreal, dan Line dalam film Ada Apa Dengan Cinta 2 dari segi sifat iklannya.

\section{TINJAUAN PUSTAKA}

Penelitian ini menggunakan beberapa teori yang dilandasi dengan konsep dan pengertian yang merujuk pada analisis penempatan produk.

Sebagai salah satu perantara antara produsen dan khalayak atau konsumen, media merupakan salah satu hal terpenting yang harus ada. Tanpa adanya media sebuah pesan atau arus informasi tidak dapat sampai kepada khalayak umum atau penerima pesan tersebut. Menurut KBBI (1994) media adalah alat (sarana) komunikasi seperti koran, majalah, radio, televisi, film, poster, dan spanduk yang terletak di antara dua pihak (orang, golongan, dan sebagainya). Media yang digunakan dalam penelitian ini termasuk media massa. Media massa merupakan sarana menciptakan atau mendaur ulang tanda untuk mencapai tujuan (Danesi, 2010). Media massa dibagi menjadi beberapa jenis yaitu media massa cetak, media massa elektronik, dan media massa online. Industri budaya membuat mediamedia budaya (Adorno \& Horkheimer dalam Narendra et al., 2019), seperti televisi, radio, surat kabar, majalah, film, dan musik, termasuk iklan.

Iklan merupakan suatu bentuk komunikasi nonpersonal yang menyampaikan informasi secara berbayar dan sesuai dengan keinginan pihak pengiklan atau pemasang iklan. Iklan merupakan media nonpersonal, karena iklan melibatkan media massa di dalamnya seperti TV, koran ,dan radio. Iklan ditunjukkan untuk mempengaruhi afeksi dan kognisi konsumen. Tujuannya untuk mempengaruhi perhatian atau minat beli konsumen secara tidak langsung. Iklan adalah segala bentuk presentasi nonpribadi dan promosi gagasan, barang, atau jasa 
oleh sponsor tertentu yang harus dibayar (Kotler \& Keller, 2007). Pengiklanan suatu produk adalah cara yang paling tepat untuk menjual produk yang dibuat, karena iklan salah satu bentuk promosi yang paling banyak dibahas orang. Tujuan utama yang ingin dicapai iklan adalah ingin mempengaruhi melalui gambarangambaran tertentu dalam pesan-pesan promosinya, dengan demikian iklan mempengaruhi individu maupun kelompok melalui citra merek dan pesan yang diusung (Murtono, 2009).

Iklan terdapat beberapa jenis dan sifat. Fandy Tjiptono mengklasifikasikan jenis iklan berdasarkan berbagai aspek, di antaranya dari aspek isi pesan, tujuan, dan pemilik iklan (Tjiptono, 2005). Lebih jauh, jenis iklan menurut mempunyai sifatsifatnya (Tjiptono, 2005), sebagai berikut: 1) Public presentation, memungkinkan setiap orang menerima pesan yang sama tentang produk yang diiklankan; 2) Persuasiveness, pesan iklan yang sama dapat diulang-ulang untuk memantapkan penerimaan informasi; 3) Amplifed Expresiveness, iklan yang mampu mendramatisasi perusahaan dan produknya melalui gambar dan suara untuk menggugah dan mempengaruhi perasaan khalayak; dan 4) Impersonality, iklan tidak bersifat memaksa khalayak untuk memperhatikan dan menanggapinya, karena merupakan komunikasi yang monolog (satu arah).
Salah satu promosi yang mudah dilakukan oleh pihak pemasar atau produsen adalah dengan menempelkan atau menyisipkan produknya ke suatu program atau film yang akan ditayangkan. Inovasi dan kreasi dalam dunia periklanan promosi tidak hanya terbatas dengan media klasik yang sudah digunakan sejak zaman dahulu. Perkembangan teknologi juga mendorong apapun media yang dipilih dapat dijadikan sebagai media riil yang akan digunakan untuk menyampaikan pesan atau mempromosikan sebuah produk barang atau jasa. Produsen dapat memasarkan produknya dengan cara apapun yang dapat mengundang konsumen untuk membeli produknya. Sekarang ini banyak sekali cara untuk memasarkan produk yang dijual, mulai dari mengiklankanya di televisi, koran, radio atau bahkan ditempelkan di baliho jalan. Banyak produsen yang memilih cara yang unik untuk menjual produknya. Salah satu promosi yang mulai banyak dilakukan pemasar adalah product placement program televisi atau film.

Pengertian lain dari product placement adalah penempatan yang dilakukan melalui program media tertentu yang ditujukan untuk meningkatkan visibilitas sebuah merek atau produk dan jasa. Penempatan yang dilakukan secara halus dan merupakan satu kesatuan dari media yang digunakan sehingga diharapkan visibilitas merek akan terangkat (Avery \& Ferraro, 2000).

Penyisipan iklan pada suatu program ini sering disebut dengan 
penempatan produk. Penempatan produk didefinisikan sebagai pesan produk yang dibayar dengan sasaran mempengaruhi audience film atau televisi melalui pencakupan suatu produk secara terencana dan halus ke dalam film atau program televisi (Shrum, 2010). Awal kemunculannya pada tahun 1940, penempatan produk tidak begitu diperhatikan oleh para produsen, karena dianggap kurang efektif. Namun, tahun 1980-an penempatan produk pada sebuah film sangat intensif dan besar kesuksesannya.

Kasus penempatan produk dalam film Ada Apa Dengan Cinta 2 tampak banyak sekali produk yang dapat dilihat, seperti Aqua, Loreal Paris, Garuda Indonesia, Lenovo, dan lain-lain. Film Ada Apa Dengan Cinta 2 adalah film yang sangat ditunggu oleh para penikmat film, maka tidak heran jika banyak produsen yang tertarik untuk memasang produknya di film ini. Penempatan produk dalam film ini tidak hanya ditampilkan dalam adegan-adegan yang ada saja, melainkan sampai dengan pembuatan produk-produk khusus juga menampilkan artis yang bermain pada film Ada Apa Dengan Cinta 2.

\section{METODE}

Penelitian ini menggunakan jenis penelitian Deskriptif Kualitatif, adalah penelitian yang mengarah pada pendeskripsian secara rinci dan mendalam baik kondisi maupun proses, dan juga hubungan atau saling keterkaitannya mengenai hal-hal pokok yang ditemukan pada sasaran penelitian (Sutopo, 1996). Objek yang diteliti adalah beberapa produk yang sengaja disisipkan dalam film Ada Apa Dengan Cinta 2. Beberapa produk yang secara sengaja disisipkan dalam film ini, yaitu Aqua, Lenovo, L'oreal Paris, Line, Walls Magnum, Garuda Indonesia, Simpati, Fujifilm, dan Mitsubishi, namun hanya tiga produk saja yaitu Aqua, Loreal, dan Line yang dijadikan sampel penelitian. Pemilihan ketiga produk tersebut dengan dasar teknik pengambilan data yang digunakan adalah teknik Purposive Sampling. Analisa data menggunakan metode Visual Interpretatif, khususnya Analisis Video Interpretatif (Interpretative Video-Analysis). Video berupa film Ada Apa Dengan Cinta 2 dianalisis adegan per adegannya berdasarkan sifat iklan yang terdapat di dalamnya secara deskriptif kualitatif.

\section{PEMBAHASAN}

\subsection{Film Ada Apa Dengan Cinta 2}

Film Ada Apa Dengan Cinta 2 merupakan sekuel dari film sebelumnya yang berjudul Ada Apa Dengan Cinta? (AADC) dan dirilis pada tanggal 7 Februari 2002 Film Ada Apa Dengan Cinta 2 dirilis pada bulan April 2016 tersebut mampu menarik minat penonton, yang dapat dilihat dari viewer-nya mencapai 3,6 juta penonton. Film Ada Apa Dengan Cinta 2 ini merupakan film jawaban atas rasa penasaran penonton film AADC yang pada bagian akhir cerita 


\section{CAPTURE}

dibuat seperti menggantung. Film yang diproduseri oleh Mira Lesmana ini membutuhkan waktu selama 14 tahun untuk memutuskan untuk membuat sekuelnya. Film yang ber-genre drama ini diperankan oleh Dian Sastrowardoyo, Titi Kamal, Adinia Wirasti, Sissy Precillia, Nicholas Saputra, dan Dennis Adiswhara, pemeran yang sama dengan film Ada Apa Dengan Cinta?.

Film Ada Apa Dengan Cinta? (AADC 1) merupakan film yang sukses pada saat itu, maka tidak heran ketika film Ada Apa Dengan Cinta 2 (AADC 2) dirilis, banyak penggemar yang penasaran ingin menonton. Perbedaan yang terjadi pada kedua film ini adalah lokasi syuting yang digunakan pada AADC 1 hanya di Indonesia saja, sedangkan AADC 2 menggunakan dua lokasi yaitu Indonesia dan New York. Film AADC 2 yang berdurasi 2 jam ini ditayangkan di tiga negara yaitu Indonesia, Malaysia, dan Brunei. Penayangan film AADC 2 ini ditayangkan serentak pada tanggal 28 April 2016.

\subsection{Penempatan Produk dalam Shot}

Sebagai film yang sudah ditunggutunggu kehadirannya oleh penonton, menjadikan film ini layak menjadi target iklan melalui penyisipan sebuah produk dalam film. Rata-rata para pemasar yang menyisipkan produknya dalam film ini merupakan produk yang memang sesuai dengan kehidupan anak muda, karena film ini merupakan film drama percintaan anak muda.
Fokus analisis penempatan produk dalam film tiga produk yang menjadi sampel penelitian, kemudian mendeskripsikan bagaimana sifat penempatan produknya ke dalam teks. Hasil analisis menunjukkan pada film Ada Apa Dengan Cinta 2 ini terdapat empat sifat iklan yaitu: Public Presentation, Persuasiveness, Amplified Expresiveness, dan Impersonality. Berikut paparan penempatan produk dalam film ini.

\subsubsection{Penempatan Produk sebagai}

\section{Public Presentation}

Adegan pada timecode 00:38:18 00:38:23 menceritakan tentang Cinta dan teman-temannya yang sedang makan siang di sebuah kedai kopi di Yogyakarta. Adegan tersebut memperlihatkan Cinta dan temantemannya sedang membicarakan sesuatu mengenai Rangga. Adegan tersebut menunjukkan bahwa Milly tiba-tiba melenceng dari pembicaraan yang dibahas, dan mulai tidak fokus. Setting adegan tersebut tidak nampak gambar atau shot yang menunjukkan sebuah produk komersil dalam frame ini, tetapi jika dilihat dari segi audio atau suara dapat terdengar jelas jika Milly mengucapkan kata-kata "sori ta, gue lagi gak fokus nih ?'.

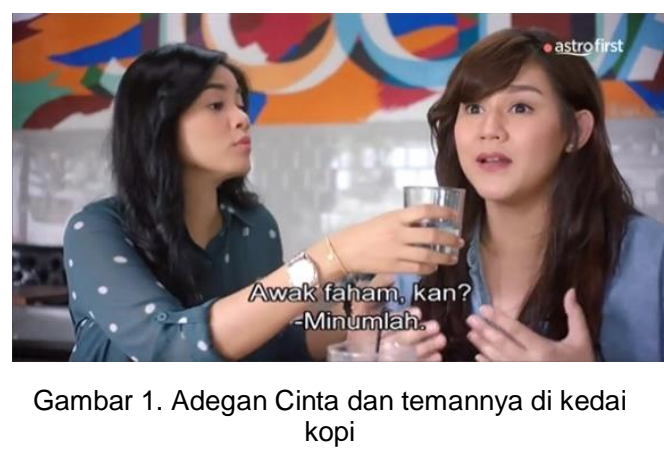


(Sumber: Film AADC2, 2016, TC: 00:38:18 00:38:23)

Kalimat tersebut memang selaras dengan tema yang sedang gencargencarnya diiklankan oleh Aqua, karena salah satu penyebab orang kehilangan konsentrasi atau kehilangan fokus adalah kekurangan cairan tubuh. Adegan pertama memiliki sifat Public Presentation karena adegan tersebut mengandung pesan yang disampaikan kepada khalayak namun tidak nampak secara visual. Hal itu dapat dilihat pada dialog yang diucapkan oleh pemeran tersebut yang berbunyi "sorry ta, gue lagi gak fokus nih!". Hal ini menjelaskan bahwa kata-kata Milly tersebut selaras dengan tema yang diusung iklan Aqua. Maka, secara tidak langsung orang atau khalayak yang menerima pesan tersebut juga sudah melihat pesan yang sama dari iklan produk Aqua yang ditampilkan di media lain.

\subsubsection{Penempatan Produk sebagai}

\section{Persuasiveness}

Penempatan produk sebagai Persuasiveness dalam film ini terdapat dalam dua adegan, sebagai berikut.

1). Penempatan produk pada adegan 1

Adegan pada timecode 00:51:25 00:56:06 menceritakan tentang pertemuan Rangga dan Cinta untuk pertama kalinya setelah 14 tahun tidak bertemu. Sebenarnya Cinta sudah tidak ingin menemui Rangga, namun karena paksaan dari temantemannya, akhirnya Cinta mau menemui Rangga. Mereka terlihat duduk berhadapan dan mengungkapkan maksud pertemuan ini. Cinta terlebih dahulu memulai percakapan. Cinta menjelaskan ia mau menemui Rangga karena desakan temannya, agar Rangga tidak salah paham atau berpikiran yang lain.

Adegan ini juga memperlihatkan beberapa shot yang hanya memperlihatkan botol Aqua. Adegan ini juga tampak benar nilai komersialnya, karena gambar yang diambil dalam adegan ini adalah pada saat Cinta akan mengambil air minumnya, yang seharusnya tidak perlu diambil dengan medium close up. Selain itu, kemasan Aqua yang digunakan dalam adegan tersebut merupakan kemasan Aqua reflection 380 $\mathrm{ml}$. Aqua reflection merupakan kemasan premium dari Aqua. Biasanya dapat dijumpai di restoran dan tempat premium lainnya.

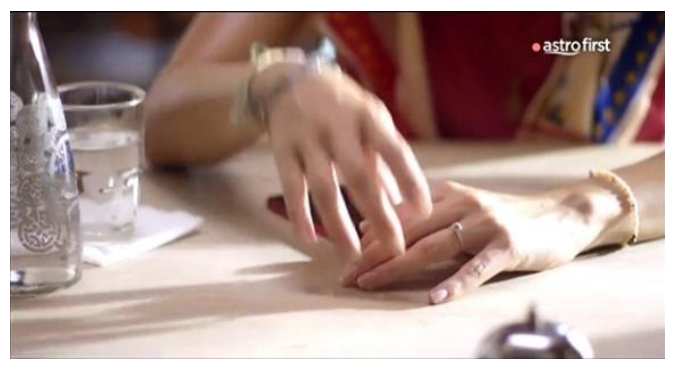

Gambar 2. Produk Aqua dalam adegan pertemuan Cinta dan Rangga

(Sumber: Film AADC2, 2016, TC: 00:51:25 $00: 56: 06)$

Penampakan produk Aqua yang memang sengaja ditempatkan di atas meja dalam adegan kedua tersebut termasuk iklan. Hal ini sesuai dengan sifat iklan Persuasiveness, yaitu iklan tersebut menampakkan sebuah gambar untuk mempengaruhi khalayak dan juga diulang berkali-kali untuk memantapkan informasi 


\section{CAPTURE}

yang akan disampaikan.

2). Penempatan produk pada adegan 2

Adegan ini menceritakan Rangga yang berpikir mengajak Cinta untuk bertemu lagi. Cinta memang berniat melupakan kejadian itu, dan menceritakannya kepada Trian tentang semua hal yang dialami selama di Yogyakarta. Cinta merasa bingung apa yang harus dilakukan dan memulainya dari mana. Sampai pada akhirnya Cinta memberanikan diri untuk menceritakan pertemuannya dengan Rangga tersebut. Belum sampai Cinta menceritakan hal itu, Trian menerima telepon, dan Cinta mendapat pesan dari Rangga, yang berisi "Cinta, saya akan ke Jakarta malam ini, bisakah kita bertemu lagi ?". Cinta kaget menerima pesan itu dan tidak memperdulikan hal itu sampai Trian kembali. Penempatan produk pada Line yang digunakan Cinta terlihat kurang pas, karena sebelumnya Rangga tidak mempunyai kontak Line-nya Cinta. Selain itu, pengambilan gambar adegan ini juga seperti setengah-setengah, karena tidak jelas difokuskan apa.

Kedua gambar tidak begitu memperlihatkan pesan komersilnya, karena Line merupakan media sosial yang sudah biasa digunakan anak-anak muda untuk berkomunikasi antara satu sama lain. Penonton pun tidak akan menyadari bahwa pada adegan ini terselip nilai komersil.

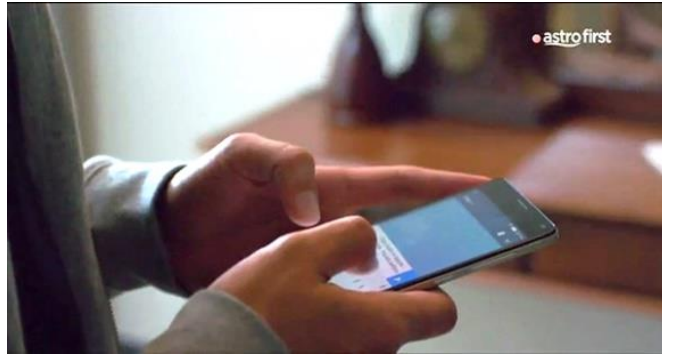

Gambar 3. Adegan Rangga mengirim pesan via Line

(Sumber: Film AADC2, 2016, TC: 01:41:32 $01: 41: 35)$

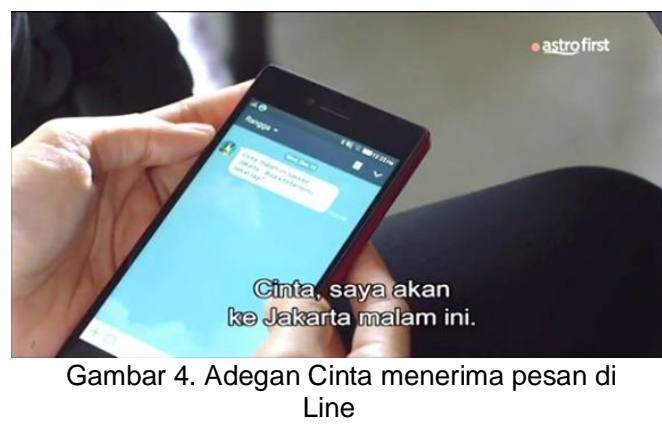

(Sumber: Film AADC2, 2016, TC: 01:41:52 $01: 41: 57)$

Gambar di atas terlihat Rangga sedang berusaha menghubungi Cinta, dan memberi tahu bahwa ia akan ke Jakarta untuk pulang menuju New York. Shot kedua menunjukkan Cinta menerima pesan dari Rangga dan hanya membacanya, karena pada saat itu Trian sedang bersamanya. Karena bingung akan menjawab bagaimana, akhirnya Cinta tidak membalas pesan dari Rangga. Kedua shot tersebut sama-sama memperlihatkan ruang obrolan dalam aplikasi Line.

Beberapa kali dalam adegan ini menampilkan aplikasi yang sedang tren tersebut. Salah satu shot yang terdapat penempatan produk Line adalah pada saat Rangga mengajak Cinta untuk bertemu kembali. Visualisasi adegan ini terlihat jelas 
bagaimana film ini menampilkan ruang obrolan aplikasi Line berulang-ulang sebagai komunikasi antara kedua pemeran utamanya. Hal ini sesuai dengan sifat salah satu iklan yaitu Persuasiveness, semua komunikasi yang tampak dalam adegan ini menggunakan aplikasi media sosial Line dan ditayangkan secara berulang-ulang untuk memantapkan pesan yang disampaikan.

\subsubsection{Penampakan Produk sebagai} Amplified Expresiveness

Penempatan produk sebagai Amplified Expresiveness dalam film ini terdapat dalam dua adegan, sebagai berikut.

1). Penempatan produk pada adegan 1

Adegan pada timecode 01:02:11 01:02:15 menceritakan tentang pertemuan Rangga dan Cinta yang sudah selesai dan bermaksud akan mengantar Cinta pulang. Setelah pertemuan yang singkat itu, Cinta merasa sudah mendapat penjelasan yang sangat jelas. Cinta memutuskan untuk menyudahi pertemuan itu dan pergi, namun Rangga memaksa untuk menemaninya mencari taksi. Awalnya Cinta tidak ingin ditemani Rangga, namun Cinta merasa tidak ada salahnya. Sebelum mereka menunggu taksi, Cinta menunggu Rangga terlebih dahulu yang sedang membeli minum untuknya. Setelah Rangga datang, kemudian mereka berdua jalan bergegas mencari taksi, di perjalanan mereka bercakap-cakap. Cinta menanyakan kabar terakhir tentang Rangga dan keluarganya. Sebelum mereka beranjak untuk mencari taksi, Cinta meminum air minum yang dibelikan Rangga tadi. Adegan sangat jelas sisi komersialnya, karena produk tersebut diminum langsung oleh pemeran utamanya. Pengambilan gambar dalam adegan ini menggunakan teknik medium close up. Penonton juga akan langsung menyadari bahwa itu merupakan iklan yang sengaja disisipkan.

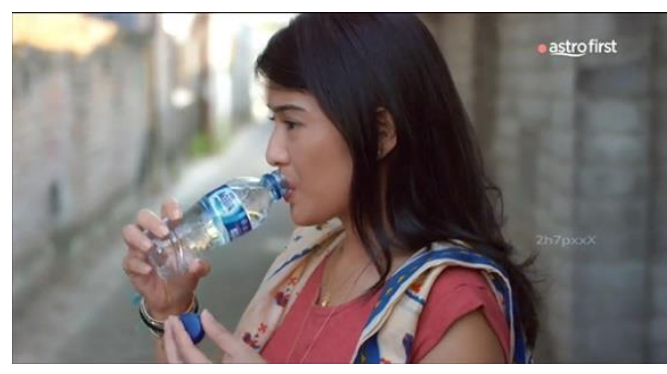

Gambar 5. Produk Aqua dalam adegan Cinta (Sumber: Film AADC2, 2016, TC: 01:02:11 01:02:15)

Tanpa menyamarkan nama merek (brand), dalam adegan ini terlihat produk Aqua sengaja ditampilkan, bahwa air mineral tersebut sangat pas untuk diminum kapan saja dan di mana saja. Adegan ini merujuk pada sifat iklan yaitu Amplified Expresiveness, yaitu adegan ini sengaja ditempatkan sebuah gambar dengan memperlihatkan nama atau merek produk untuk mempengaruhi atau menggugah kahalayak dan pemirsa untuk menggunakan produk tersebut.

2). Penempatan produk pada adegan 2

Cinta terus-menerus memikirkan pesan yang dikirim oleh Rangga. Dia merasa bingung harus menjawab seperti 


\section{CAPTURE}

apa atas ajakan Rangga. Cinta memutuskan untuk tidak menemui Rangga, dan tidak menjawab pesan Rangga. Rangga pun terus-menerus menunggu jawaban Cinta atas pertanyaan yang Rangga berikan, namun Cinta tidak juga membalas. Setelah mendengar jawaban Cinta, Rangga tampak kecewa. Rangga merasa ia harus menemui Cinta apapun resikonya dan tanpa pikir panjang lagi, akhirnya ia nekat menemui Cinta di galeri milik Cinta. Penempatan produk dalam adegan ini memperlihatkan logo Line, karena pada beberapa adegan sebelum ini hanya ruang obrolan dan audio saja yang terlihat dan terdengar. Beberapa penonton mungkin menyadari bahwa adegan ini memuat pesan komersil, karena waktu penayangan logo Line yang cukup lama.

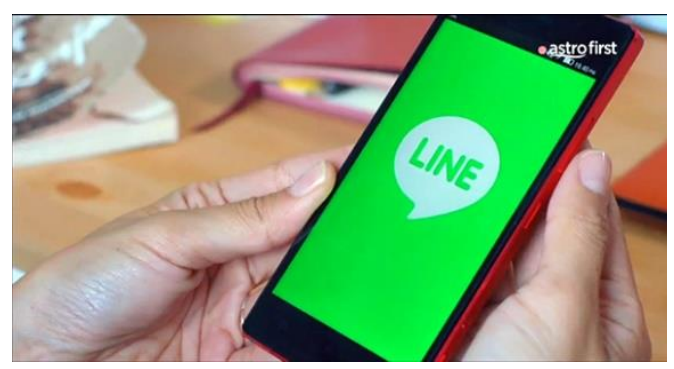

Gambar 6. Shot penampakan logo Line (Sumber: Film AADC2, 2016, TC: 01:43:03 01:43:07)

Penempatan produk dalam adegan ini juga bertujuan sebagai alat komunikasi antara pemeran utama wanita dan pria. Tidak hanya logo awal yang ditampilkan, tetapi saat percakapannya pun juga ikut ditampilkan, karena memang Line ingin menyampaikan pesan bahwa aplikasi ini memang cocok atau sesuai untuk digunakan sebagai alat atau media komunikasi.

\subsubsection{Penempatan Produk sebagai Impersonality}

1). Penempatan produk pada adegan 1

Adegan pada timecode 00:45:50 00:45:52 menceritakan Rangga nekat menyusul Cinta dan menemuinya, atas informasi yang diberikan oleh Karmen. Cinta dan teman-temannya yang pada saat itu tengah menikmati pameran Eko Nugroho terkejut dengan kedatangan Rangga. Dia memutuskan untuk pulang ke Jakarta lebih awal, karena merasa kecewa dengan apa yang dilakukan Karmen. Pengambilan gambarnya terlihat sekali untuk keperluan komersil, satu paket alat kecantikan diperlihatkan dalam satu adegan, meskipun saat adegan mencapai klimaks, tetapi masih saja disisipkan unsur iklan tersebut.

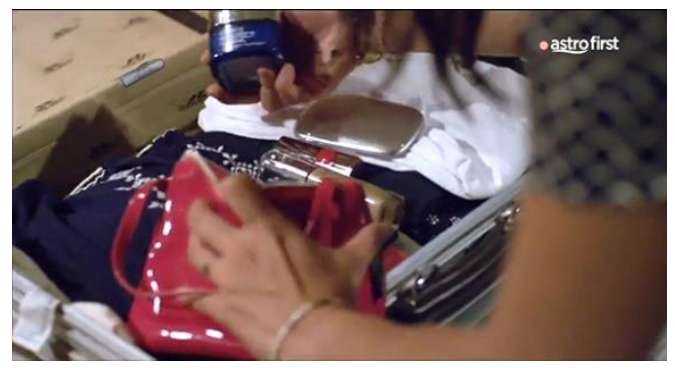

Gambar 7. Adegan memperlihatkan satu paket alat kecantikan Cinta

(Sumber: Film AADC2, 2016, TC: 00:45:50 00:45:52)

Pengambilan gambar tersebut memperlihatkan begitu banyak produk kecantikan yang memang sengaja ditampilkan, yaitu produk Loreal menjadi nama brand-nya. Adegan ini memang sedikit terlihat penempatan produknya, tetapi iklan ini tidak bersifat terlalu memaksa 
penonton, karena penampakan produk Loreal tidak terlalu menyolok dan fokusnya lebih pada adegan yang sedang berlangsung. Hal inilah yang disebut Impersonality.

2). Penempatan produk pada adegan 2

Penempatan produk sebagai Impersonality juga tampak pada adegan di timecode 00:50:44 - 00:50:48 dan 00:51:05 - 00:51:08. Adegan ini menceritakan keputusan Cinta untuk menemui Rangga dan bermaksud menyelesaikan masalahnya. Keesokan harinya Cinta bergegas menemui Rangga, ia tampak gelisah dan tidak sabar. Layaknya seorang perempuan yang akan menemui kekasihnya, Cinta bingung menentukan riasan apa yang akan dipakainya untuk menemui Rangga. Cinta tampak melihat sekeliling dulu memastikan apakah ada temannya atau tidak sebelum merias wajahnya. Meja rias Cinta tampak berantakan, dapat dilihat di atas meja terdapat beberapa lipstick, bedak, dan peralatan make up lainnya. Cinta mencoba beberapa lipstick untuk menemukan warna yang cocok di bibirnya. Pesan komersil dalam adegan ini terlihat sangat pas, karena diletakkan pada adegan pemeran utama wanita sedang bingung memilih lipstick warna apa yang akan digunakannya. Terlebih nilai komersilnya juga terdapat pada penempatan produknya, karena dalam gambar terlihat banyak pilihan lipstick yang diperlihatkan di atas meja. Hal itu seakan menunjukkan bahwa Loreal mempunyai banyak varian warna lipstick.

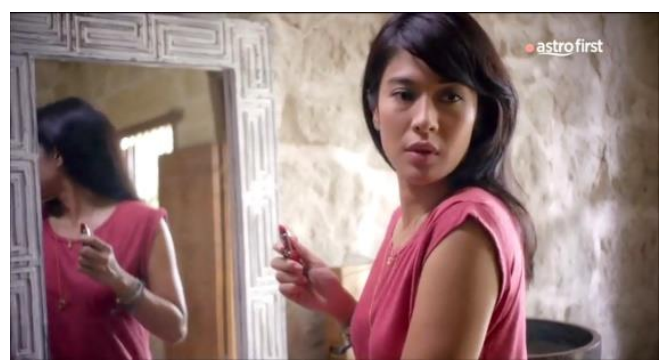

Gambar 8. Adegan Cinta memilih lipstik (Sumber: Film AADC2, 2016, TC: 00:50:44 $00: 50: 48)$

Gambar 8 memperlihatkan Cinta sedang memilih lipstick apa yang akan dikenakan untuk menemui Rangga. Tampak pada gambar ini juga Cinta sedang memperhatikan sekitarnya, apakah ada temannya ataukah tidak. Gambar 9 memperihatkan banyak sekali produk Loreal milik Cinta yang dibiarkan berantakan begitu saja.

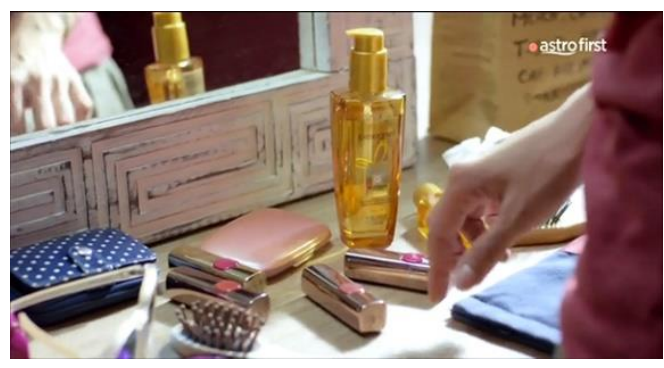

$$
\begin{gathered}
\text { Gambar 9. Lipstik di atas meja rias } \\
\text { (Sumber: Film AADC2, 2016, TC: 00:51:05 - } \\
\text { 00:51:08) }
\end{gathered}
$$

Adegan ini memperlihatkan produk Loreal dimasukkan dalam adegan ini, tetapi tidak bersifat mempengaruhi khalayak secara langsung. Penempatan beberapa produk varian dari Loreal terlihat jelas pada salah satu shot, akan tetapi iklan yang disisipkan tersebut tidak memerlukan respon langsung dari khalayak, karena 


\section{CAPTURE}

pesan yang ingin disampaikan adalah satu arah saja. Hal ini menunjukkan bahwa adegan ini bersifat Impersonality.

3). Penempatan produk pada adegan 3

Selain ketiga adegan di atas, masih dijumpai penempatan produk sebagai Impersonality, yaitu pada timecode 01:24:22 - 01:24:25. Cerita pada adegan ini menggambarkan tentang pertemuan Rangga dan Cinta yang belum selesai. Cinta dan Rangga terus bercerita sampai Cinta lupa kalau telah ada janji dengan teman-temannya. Sebelum Cinta menyadari bahwa ia sudah ada janji, Rangga seakanakan mengulur-ulur waktu agar Cinta tidak segera ingin pulang. Rangga terus mengajak Cinta ke tempat-tempat baru yang belum pernah Cinta kunjungi. Tanpa terasa mereka sudah bersama selama seharian, dan Rangga masih tetap mengajak Cinta untuk menikmati keindahan kota Yogyakarta. Seharian mereka berjalan dan bercerita, sampai Cinta menyadari wajahnya sudah mulai pucat dan ia harus menambah riasannya agar terlihat segar di hadapan Rangga. Penempatan produk dalam adegan ini juga terkesan halus dan sesuai alur, karena memakai riasan adalah salah satu kegemaran wanita, dan juga merupakan salah satu cara wanita agar terlihat tidak pucat. Pesan komersil dalam adegan ini juga tidak begitu terlihat menonjol, penempatannya yang pas membuat adegan ini terlihat natural. Bahkan, ada beberapa orang yang mungkin tidak menyadari bahwa hal itu termasuk salah satu iklan dalam film ini.

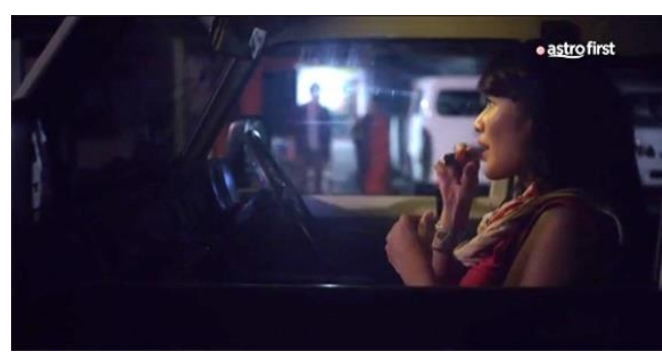

Gambar 10. Adegan merias bibir di dalam mobil (Sumber: Film AADC2, 2016, TC: 01:24:22 $01: 24: 25)$

Adegan di atas tidak begitu memperlihatkan penempatan produknya, karena tidak terlihat ada sebuah brand atau merek yang dipaksa muncul dalam satu frame. Frame tersebut menjelaskan bahwa Cinta sedang memakai produk kosmetik Loreal, namun tampak samar. Penampakan iklan seperti ini disebut Impersonality, karena Loreal tidak secara langsung menjelaskan lewat sebuah gambar atau frame, hanya melalui rangkaian alur jalan cerita yang sengaja tidak membutuhkan respon langsung dari khalayak atau pemirsa.

4). Penempatan produk pada adegan 4

Adegan ini menceritakan tentang hari terakhir Cinta dan teman-temannya menikmati liburan. Sampai siang, Cinta belum juga kembali dari pertemuannya dengan Rangga. Karmen, Maura, dan Milly sudah khawatir memikirkan Cinta, karena sebelumnya Cinta hanya pamit sebentar saja untuk menemui Rangga dan menjelaskan permasalahan antara dirinya dan Rangga, namun hingga seharian Cinta 
belum juga kembali. Setelah temantemannya menunggu Cinta cukup lama, akhirnya Cinta kembali dan temantemannya langsung menanyakan keadaannya. Setelah istirahat sejenak Cinta diminta teman-temannya untuk menceritakan kejadian apa saja yang terjadi pada saat mereka bertemu. Cinta menolak untuk menceritakan semua kejadian pada saat mereka bertemu, kemudian Cinta teringat kalau waktu sudah dekat dengan keberangkatan pesawat untuk pulang ke Jakarta. Cinta bergegas menuju kamar untuk bersiap-siap pulang. Penempatan produk dalam adegan ini terlihat tidak begitu jelas, karena penempatannya yang menyamping dan itu membuat produknya sedikit tidak terlihat.

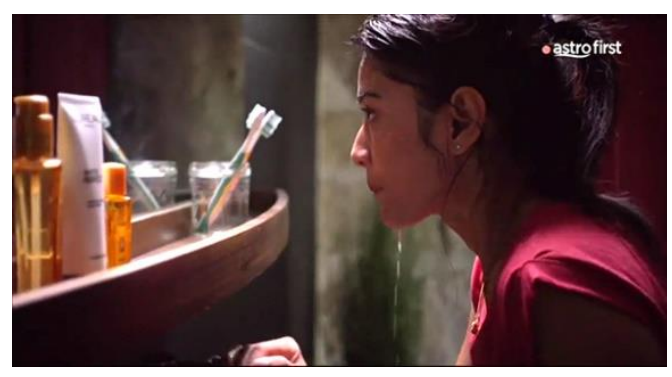

Gambar 11. Penempatan produk saat Cinta berias diri

(Sumber: Film AADC2, 2016, TC: 01:34:40 $01: 34: 52)$

Penempatan produk dalam adegan ini tidak terlihat begitu jelas, karena produk kecantikan Loreal ditempatkan di samping kiri. Adegan ini merupakan iklan yang tidak memerlukan respon langsung dari khalayak, oleh karena itu penempatan produk Loreal dalam adegan ini masuk kategori Impersonality. Komunikasi dalam iklan tidak memaksa penonton atau khalayak memberikan respon berlebih pada iklan tersebut.

\section{SIMPULAN}

Penempatan produk (product placement) dalam sebuah program televise ataupun film, dapat menjadi pilihan bagi beberapa produsen untuk mempromosikan produknya, namun produsen harus pandai memilah-milah media yang akan dipilinnya. Product placement dalam film merupakan salah satu strategi periklanan agar produk atau iklan layanan masyarakat yang diiklankan tersebut dapat dilihat oleh pemirsa film.

Penempatan produk dalam film Ada Apa Dengan Cinta 2 ini tampak penyisipannya halus dan rapi, namun ada beberapa merek yang sengaja ditampilkan secara menonjol baik produk ataupun logonya. Hasil analisis menunjukkan pada film Ada Apa Dengan Cinta 2 ini terdapat empat sifat iklan yaitu: Public Presentation tampak pada 1 adegan, Persuasiveness tampak pada 2 adegan, Amplified Expresiveness tampak pada 2 adegan, dan Impersonality tampak pada 4 adegan.

Setiap produk yang disisipkan dalam film ini mempunyai sifat yang berbeda-beda. Aqua pada film ini memiliki sifat yang berbeda-beda: adegan pertama mempunyai sifat public presentation, adegan kedua mempunyai sifat persuasiveness, dan adegan ketiga mempunyai sifat amplified expressiveness. Berbeda dengan Aqua tersebut, produk 


\section{CAPTURE}

Loreal memiliki kesamaan sifat pada setiap adegannya yaitu impersonality, begitupun sama halnya dengan Line yang memiliki sifat yang sama pada setiap adegannya yaitu persuasiveness.

\section{DAFTAR ACUAN}

Ali, Moh. M., \& Sugihartono, R. A. (2015). Teknik Editing pada Film Rectoverso dalam Mewujudkan Cerita. CAPTURE: Jurnal Seni Media Rekam, 6(2), 69-84.

Avery, R. J., \& Ferraro, R. (2000). Verisimilitude or Advertising? Brand Appearances on Prime-Time Television. The Journal of Consumer Affairs, 34(2), 217-244.

Danesi, M. (2010). Pengantar Memahami Semiotika Media. Jalasutra.

Kotler, P., \& Keller, K. L. (2007). Manajemen Pemasaran (Terj. Benyamin Molan). Indeks.

Murtono, T. (2009). Identitas Lokal dan Global dalam Iklan. Acintya Jurnal Penelitian Seni Budaya, 1(1), 1-19.

Narendra, A. N., Habsari, S. K., \& Ardianto, D. T. (2019). Form of Standardization and Stereotyping Practices through Message of Video Ads Buavita. CAPTURE: Jurnal Seni Media Rekam, 10(2), 107-125.

https://doi.org/10.33153/capture.v1 $0 \mathrm{i} 2.2243$

Shrum, L. J. (2010). Psikologi Media Entertainment. Jalasutra.

Sutopo, H. (1996). Metodologi Penelitian Kualitatif. UNS.

Tjiptono, F. (2005). Manajemen dan Strategi Merek. Andi. 